\title{
The Effect of Bintaro (Cerbera manghas) Leaf Extract on Transmission of Aphids (Homoptera) in Chili (Capsicum annuum) Plants
}

\author{
Achmadi Susilo ${ }^{1}$, Dwi Haryanta ${ }^{2}$,Tatuk Tojibatus Sa'adah ${ }^{3}$ \\ ${ }^{1,2,3}$ Faculty of Agriculture, University of Wijaya Kusuma Surabaya \\ Email: dwi.haryanta@yahoo.com
}

Received: November 19. Revised: December 18, 2020. Accepted: December 21, 2020. Published: December 24, 2020

\begin{abstract}
One of the threats in the cultivation of chili is the presence of aphids attack. The study aims to determine the effect of bintaro / (Cerbera manghas)leaf extract spraying as a bio-pesticide on the transmission patterns of aphids in chili plants.The experimental method refers to the Painter resistance test(Painter, 1951). Factorial experiment with factor I treatment was the concentration of bintaro leaf extract with six levels namely $0.0 \%$ concentration; 2.5\% concentration; $\quad \mathbf{5 . 0 \%}$ concentration; 7.5\% concentration; $10.0 \%$ concentration; and 12.5\% concentration. Factor II treatment was the frequency of spraying namely F1 sprayed once a week (sunday), and F2 is sprayed twice a week (Sunday and Wednesday). Overall there are 12 treatment combinations. The experimental unit is a polybag planted by one stem of chili per polybag so that it requires 60 plant polybags, carried out in a controlled field from the presence of other animals by covering it with a mosquito net. In the inside of the lid of mosquito net is infested with chili plants which are attacked by aphids. Source of inoculum of one plant stem attacked by aphids for each containment/lid (each experimental group).The number of insects that transmitted to the treatment plants was observed every two days or before spraying, while the damage to plants at the end of the experiment. The results showed that there were two types of aphids that attacked the inoculum source plant namely Bemesia tabaci (whitefly) and Aphis gossypii (Aphid) and there were symbionts in the form of black ants (Dolichoderus thoracicus Smith).
\end{abstract}

Transmission occurs since one day after infestation. Population density of the three insect species in each treatment was significantly different, there was an interaction between treatment concentrations with the frequency of bintaro leaf extract spraying, but the density was not consistent from one observation to the next. Plant damage occurs in all plants and the frequency of spraying can reduce damage to the chili plants.

Keywords - bintaro leaf extract, aphids, chili

\section{INTRODUCTION}

In chilli cultivation is inseparable from plant pest organisms/OPT (organisme pengganggu tanaman), namely pests, diseases and weeds.One of the important pests that attack chilli plants either organically and conventionally cultivated is the aphids of Aphis gossypii Glover (Homoptera: Aphididae). Aphids is one of the important pests in vegetable crops, especially in the lowlands. curly virallosses incurred as pests reach $35 \%$ and as curly virus vectors can result in losses of up to $90 \%$. In controlling pests, farmers generally use chemical pesticides. The widespread and continuous use of pesticides can reduce losses due to pest attacks. However, the use of these chemical pesticides poses serious new problems namely pest resistance and resurgence, loss of natural enemies of pest insects, death of pollinating insects and other hazards to livestock and humans. To reduce this impact the plant pest control can be done by using plants that have the potential as botanical insecticides [1].

The use of plant extracts as bio insecticides or biopesticides has been widely recommended to farmers. Information on biopesticides is generally still limited to plant raw materials and target pests. The recommended technology is still conventional or traditionalThere are twelve types of plants that are recommended by agricultural extension workers in 20 countries, namely garlic (Allium sativum), neem (Azadirachta 
indica), chilli (Capsicum spp.), weed(Chromolaena odorata), gliriside (Gliricidia sepium), Melia azedarach, noni (Moringa oleifera), tobacco (Nicotiana tabacum), Ocimum gratissimum), tephrosia (Tephrosia vogelii), tree marigold (Tithonia diversifolia), and bitter leaf (Vernonia amygdalina)[2].Extract concentration of $50 \%$ is the most effective, environmentally friendly, inexpensive and effective method of controlling future pests(Lawal, Aliyu\&Adamu, 2015) .Botanical insecticides continue to attract attention for small farmers and the environment worldwide, considered as an alternative to synthetic insecticides. The use of secondary metabolites by extracting plants is a tradition more than 3000 years ago. Intensive research on various commercial products still cannot meet global demand for biopesticides (Pavela, 2016). The use of plant extracts and botanical insecticides are biopesticides that do not pollute the environment, and can be included in Integrated Pest Control (IPC)) programs and organic farming [3].

Bintaro (Cerbera manghas) plant which is widely known by the public today is widely used for greening as well as urban ornamental plants. Plant from the genus Cerbera has the potential to be antifungal, insecticide, antioxidant, and antitumor [4], andCerbera manghas can give a significant effect on the mortality of termites (Coptotermes sp.) with an extract concentration of $10 \%[5]$. This is because bintaro contains cerberine compounds which are toxic and can kill insects[6].Cerbera odollam extract has a significant effect on mortality and inhibits the development of Eurema spp. insect pests by giving a concentration of $1 \%$. Cerbera odollam seed extract can affect the bioactivity of Pteroma plagiophlepslarvae and Spodoptera litura F. Cerbera odollam has secondary metabolite compounds, such as saponins, polyphenols and alkaloids and terpenoids. Secondary metabolite compounds containing $\mathrm{N}$ (such as alkaloids and saponins), and the phenol group compounds (such as flavonoids and tannins) are polar so it can be dissolved in polar or semipolar solvent, such as methanol. Each of secondary metabolite compound has a different working power as an insecticide with various mechanisms[7].

Bintaro plants are almost never attacked by pests, so it is hoped that host plants that are sprayed (treated) with bintaro plant extracts will be protected from insect pests as bintaro plants. Need to look for biopesticide ingredients with abundant availability so that they are easily available and inexpensive. This study aims to examine the ability of bintaro leaf extract in rejecting the presence of aphids in chili plants. The results of the study could become information or a reference for the utilization of Bintaro plant waste which abundant in the city of Surabaya as an organic pesticide in urban farming practices.

\section{MATERIAL AND METHOD}

Study on the repellency of bintaro leaf extracts toward the Aphids (Homoptera)- Repellency test of bintaro leaf extract on the hemiptera order insects using Aphis sp. in chili plants. The test method uses the Painter plant resistance test approach (Painter, 1951), namely chilli plants treated with various concentrations of bintaro leaf extract infested by Aphis $s p$ insect. Plants that are not visited by insects or the effect of the smallest insects are then considered to have a repellency power.

Factorial experiment with factor I treatment was the concentration of bintaro leaf extract sprayed on six levels of chilli plants namely: $\mathrm{K}_{0}$ :concentration of $0,0 \%$; $\mathrm{K}_{1}$ :concentration of $2,5 \% ; \mathrm{K}_{2}$ :concentration of $5,0 \%$; $\mathrm{K}_{3}$ :concentration of $7,5 \% ; \mathrm{K}_{4}$ :concentration of $10,0 \%$; and $\mathrm{K}_{5}$ :concentration of $12,5 \%$. Factor II treatment was the frequency of spraying namely F1 sprayed once a week (sunday), and F2 is sprayed twice a week (Sunday and Wednesday). There are 12 treatment combinations. The experimental unit is a polybag planted by one stem of chili per polybag so that it requires 60 plant polybags, carried out in a controlled field from the presence of other animals by covering it with a mosquito net.

An illustration of the method of implementation is to design a controlled place (with a mosquito net lid), in the middle are placed insects that will be tested with the condition that active moves to get the host, and around it we place the test units according to the treatment. Experimental variable is the response of insects released in the middle in visiting materials that have been treated with bintaro leaf extract.

In addition to the above method (insects are left to choose), experiments are also conducted to determine the response of insects that are given the feed that has been treated with bintaro leaf extract.

Preparation of Test Insect for Chili Plants Aphids. Healthy chili plants aged 6 weeks after planting placed in the middle of a chili garden which indicated to be attacked by aphids. Plants that have been infected by aphids with a population density of 200-400 tails per plant with a population structure of nymphs and adults taken as a source of inoculum in the experiment. It is very possible that aphids that attacks chili plants of prospective inoculant more than one species, or even followed by other insects associated with aphids.

Preparation of Bintaro Leaf Extract. The making of bintaro leaf extracts using water solvents. Fresh healthy bintaro leaves are washed and then air dried. The clean leaves are cut into small sizes and extracted using a homogenizer or blender for 15 minutes. The solution is then filtered with a cloth and the liquid is an extract that will be used for the experiment. In order to be more effective in the extract liquid need to be added with the soap amounted to 2 grams of per liter of liquid. Concentration uses a ratio of the weight of leaves and water as a solvent, for example to get a concentration of 5\%, then as much as 50 grams of bintaro leaves are extracted with $1000 \mathrm{cc}$ of water,

Experimental variable is the average number of each insect of aphids or insects associated with aphids. Observations were made on the day of treatment (before spraying) and two days after treatment. Because spraying is carried out every Sunday and Wednesday, then observations are conducted on Tuesday, Wednesday, Friday and Sunday. Besides that it also measured the level of plants damage by scoring method at the end of the observation (one month since the source of the inoculum was included in the experimental plant lid). The spraying of chilli plants with bintaro leaf extract according to the treatment is still conducted until the end of the experiment. 


\section{RESULTS AND DISCUSSION}

Research Result- There were two types of aphids that attacked the inoculum source plant namely Bemesia tabaci (whitefly) and Aphis gossypii (Aphid) and there were symbionts in the form of black ants (Dolichoderus thoracicus Smith). The insect population at each source of inoculum is very high (more than 500 individuals / plants) with adult and nymph composition. The three organisms are transmitted to the chili plants which are sprayed with bintaro leaf extracts in a lid. Transmission can fly for the winged, or through the media of black ants, which is also quite high in number. A description of the three types of insects is presented in Figure 4.The development of the population of the three types of insects in each treatment plant is presented in Table 1, Table 2, and Table 3.

\section{Insect population of Bemesia tabaci (Whitefly)-} Transmission of the Bemisia tabaci insect from the source of the inoculum to the treatment plant occurs starting one day after infestation. Whitefly found in treatment plants (transmission from inoculum sources) consist of the adult and nymphs phase. The average Bemisia tabaci insect population in each treatment plant from initial observation to the end is presented in Table 1.a (Figure 1.a.) and Table 1.b.(Figure 1.b.)).

Whitefly are found in all experimental plants. The results of the variance analysis of whitefly population data in each plant showed that there were significant differences between treatments (there was an interaction between concentration and frequency of treatment).In general, it can be seen that the population density on the second day decreased significantly compared to the first day, and occurred in all treatments. The population distribution looks random and inconsistent namely the highest number or the least number shifts at each observation, indicating its presence is not affected by the spraying treatment of bintaro leaf extract.

Aphis gossypii (Aphid) insect population- Transmission of Aphis gossypii insects from the source of the inoculum to the treatment plant occurs from one day after infestation. Aphid found in treatment plants (transmission from inoculum sources) consist of adult and nymphs phase. The average insect population of Aphis gossypii in each treatment plant from initial observation to the end is presented in Table 2.a Figure 2.a and Table 2.b.(Figure 2.b.).

Aphids are found in all experimental plants. The results of the variance analysis of aphids population data in each plant showed that there were significant differences between treatments (there was an interaction between concentration and frequency of treatment).Population density is relatively stable fluctuates with increases and decreases in a constant range of values.The population distribution looks random and inconsistent namely the highest number or the least number shifts at each observation, indicating its presence is not affected by the spraying treatment of bintaro leaf extract.

Black Ant (Dolichoderus thoracicus Smith) Population Transmission of black ant insects from inoculum sources to treatment plants occurs starting one day after infestation. The observed black ants in treatment plants (transmission from inoculum sources) consist of an adult phase. In addition to those found in plants, there are many black ants that are in the plant environment at the surface of the soil or in polybags that are more numerous than those in plants. The average population of black ant insects in each treatment plant from initial observation to the end is presented in Table 3.a and Table 3.b.

Black ants are found in all experimental plants and in their environment. Black ant mobility is very high, adding to the impression that the population is very high. The results of the variance analysis of black ant population data in each plant showed that there were significant differences between treatments (there was an interaction between concentration and treatment frequency). The population distribution looks random and inconsistent namely the highest number or the least number shifts at each observation, indicating its presence is not affected by the spraying treatment of bintaro leaf extract.

The Damage of Chili Plant- Symptoms of plant damage due to aphids infestation are brownish green undulating leaves, plants cannot grow due to the growing point is dead, then followed by the presence of lateral buds. The attacked leaves there are fallen earlier so that the upper leaves look fall earlier than the leaves below. Plants that have died shoots already confirmed the plant will not produce because there are no shoots where the flowers usually appear. If all shoots are damaged, then the damage score is 5 even though the leaves still look fresh and allow new shoots/buds to emerge. Damage to chili was observed 28 days after infestation of pests or on plants aged 60 days after planting. Data on chili crop damage for each treatment presented in Table 4.

All experimental plants suffered damage ranging from minor/light damage to severe/heavy damage. Severe/heavy damage with a greater score of 3 is in control plants (sprayed with a concentration of $0 \%$ ) and sprayed plants in concentrations of $5 \%$ and $10 \%$ once a week. Minor/light damage with a score below 2 is found in plants sprayed with a concentration of 7,5\% twice a week. The results of the variance analysis of damage data on chili plants showed that there were significant differences between treatments (there was an interaction between concentration and frequency of treatment). In addition, it can be seen that there is a tendency that those which sprayed twice a week are relatively lighter damage compared to those which sprayed once a week.

Discussion-Inoculum source plants attacked by two types of aphids, namely Bemesia tabaci (whitefly) and Aphis gossypii (aphid) and there are symbionts in the form of black ants (Dolichoderus thoracicus Smith). This is consistent with the research data [8]in one palm tree there are three types of insects together and symbiosis occurs with several types of black ants.The pattern of distribution of black ant populations is clustered followed the prey (food sources), and symbiosis with insect on plants [9].

Transmission of whitefly occurs a day after infestation. The whitefly population was significantly different between treatments, but it was inconsistent from one observation to the next, and the population tended to decline. The treatment plant group was in a limited space $\left(4 \mathrm{~m}^{2}\right)$ so that the treatment effect of the bintaro leaf extract concentration becomes biased, but in cumulative the bintaro leaf extracts can reduce the population 
of whitefly. In line with research [10] which concluded that garlic extract concentration of 5\% could effectively reduce the population of whitefly in chili the same with the insecticide of Imidacloprid, Bifenthrin and acetamiprid. The single treatment of ginger extract, onion, and chili can suppress the termite population, the mixture treatment of ginger extract with red onion has a termite repellency equal to $88.89 \%$ [11].Research [12] concluded that the spraying of garlic extract and chili extract with a concentration of 10 grams of material for $1000 \mathrm{cc}$ extract solution could reduce aphis insect population and increase mustard production. Brotowali (Tinospora crispa) stem extract treatment with the concentration of $3,125 \%$ caused mortality of aphids (Aphis gossypii) amounted to $(82,50 \%)$ at 24 hours after treatment, and at concentration of $25 \%$ caused mortality equal to $96.25 \%$ [11]. According to the conclusion of the study [13] the application of $75 \mathrm{ml}$ of citronella extract added with $100 \mathrm{ml}$ of water can reduce the population of brown aphid on chili almost $100 \%$.The most effective botanical pesticide of soursop extract reduced aphids and mite populations by $80 \%$ and $76 \%$. Neem extract decreased aphid population by $73 \%$, and mite population decreased by $56 \%$ [14].Plant extracts are more effective for whitefly on egg and nymphs (pre-adult) stadia [15].

Transmission of Aphis insect occurs a day after infestation. Aphis insect population significantly different between treatments, but it was inconsistent from one observation to the next, and the population tended to be constant (not decreased) meaning that the treatment of bintaro leaf extract did not affect the decrease in the aphis insect population.In accordance with the research [16]concluded that the biopesticide treatment was unable to suppress the Myzus persicae population in tobacco compared to the use of synthetic pesticides.Biopesticides cannot suppress aphis populations as the conclusion of the study[17].the treatment of spraying of biopesticide extracts of two types of plants is only able to cause death 54,4 and 75\% of aphids insect far below 4 types of synthetic pesticides which on average cause death above $90 \%$ at 48 hours after treatment.Research [18]concluded that gamal leaf extract contains an insecticide that can cause the death of aphids (Aphis gossypii) on chili plants. Spraying of leaf extract with a concentration of 15 grams of leaves in 1000 extracts of the solution can cause the death equal to $49,8 \%$ in 96 hours after application. Papaya leaf extract can kill aphis infestation on long beans. With a concentration of 25 grams per liter the extract solution can cause the death/mortality up to 75 percent.While Polygonum flower extract with a concentration of 5\% and tobacco leaf extract with the concentration of $10 \%$ can suppress aphis populations (Myzus and Aphis gosiipii) by $70 \%$ and $65 \%$, while the azadirachtin botanical pesticide suppresses the population by $60 \%[19]$. According to research[20] the provision of tuba root extract at a dose of 45 $\mathrm{ml} / \mathrm{L}$ of water gave the highest result of aphids (Aphis gossypii) mortality amounted to $25,28 \%$, and the intensity of crop damage equal to $25,74 \%$, compared with mortality control of $13,61 \%$ and intensity of crop damage of $49,45 \%$.

Transmission of black ants occurs a day after infestation. The black ant population is significantly different between treatments, but it is not consistent from one observation to the next. The population of black ants is not pure from the source of the inoculum, at the place of the experiment there were black ants before infestation. According to research [9]in the yard around the house there are several types of ants, including black ants in symbiosis with plant insect. The distribution of ants in the yard following the availability of food, for black ants following the presence of plant insect, after conducted an infestation the plants which attacked by aphid automatically cause the black ant came directly.

The presence of two types of aphids namely Bemisia tabaci (whitefly) and Aphis gossypii (aphid) caused damage to the experimental plant.The treatment of bintaro leaf extract has no significant effect on population fluctuations of two types of aphids, namely Bemesia tabaci (whitefly) and Aphis gossypii (aphid), however, it is generally seen that plants that are sprayed twice a week have less damage than those that are sprayed once a week. This can be interpreted that the treatment of bintaro leaf extract affects the eating behavior of two aphids on chili plants. The treatment of Polygonum persicaria plant extract as a biopesticide significantly decreased the appetite of the Nomophila indistinctalis insect. The spraying of garlic extract and chili extract with a concentration of 10 grams of material for $1000 \mathrm{cc}$ extract solution can reduce damage and increase mustard production [8].

\section{CONCLUSION}

The treatment of Bintaro Leaf Extract (Cerbera manghas) did not significantly affect on the transmission and development of the population of Bemesia tabaci (whitefly) and Aphis gossypii (aphid) aphids on the chili plants.The presence of aphids is followed by a symbiont namely black ants. The treatment of bintaro leaf extract influence on the appetite of aphids seen from the intensity of plant damage. Plants with twice a week of treatment are less damaged than plants with once a week of treatment. Needs to be conducted the further research in the field with the extract concentration increased to $50 \%$ (in this study the highest was only $12,5 \%$ ).

\section{ACKNOWLEDGEMENTS}

Manuscript material is part of the scheme of penelitian dasar unggulan perguruan tinggi (PDUPT) year II from the 3 year plan. On this occasion, we would like to thank the Directorate of Research and Community Service Directorate General of Research and Development Strengthening The Ministry of Research Technology and Higher Education who has provided funding for research implementation.

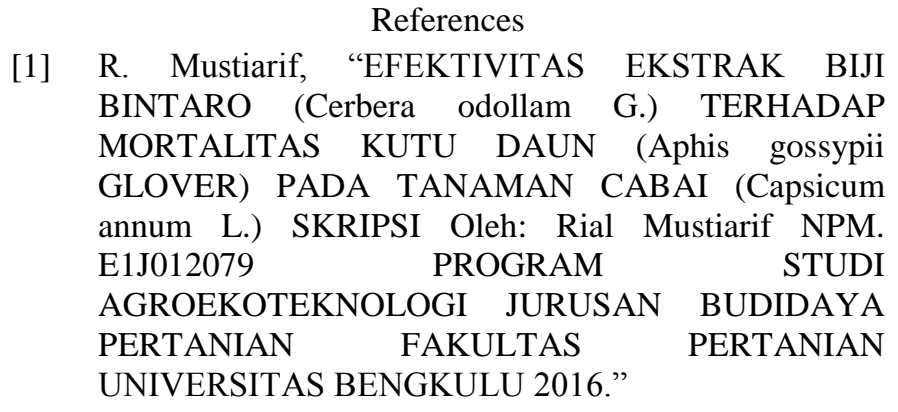


[2] J. Dougoud, S. Toepfer, M. Bateman, and W. H. Jenner, "Efficacy of homemade botanical insecticides based on traditional knowledge. A review," Agronomy for Sustainable Development, vol. 39, no. 4, p. 37, 2019.

[3] S. K. Ghosh, "Integrated field management of aphids (Myzus persicae Sulz. and Aphis gossypii Glov. Together) on potato (Solanum tuberosum L.) using biopesticides," International Journal of Science, Environment and Technology, vol. 4, no. 3, pp. 682-689, 2015.

[4] Y. XU, T. FENG, and W. TONG, "Chemical Constituents and Bioactivity of Mangrove Plants in the Genus Cerbera [J]," Journal of Guangxi Academy of Sciences, vol. 1, 2011.

[5] D. Tarmadi, A. H. Prianto, I. Guswenrivo, T. Kartika, and S. Yusuf, "Pengaruh Ekstrak Bintaro (Carbera odollam Gaertn) dan Kecubung (Brugmansia candida Pers) terhadap Rayap Tanah Coptotermes sp Influence of Bintaro (Carbera odollam Gaertn) and Kecubung (Brugmansia candida Pers) Extract against Subterranean Termite Coptotermes sp," Jurnal Ilmu dan Teknologi Kayu Tropis, vol. 5, no. 1, pp. 38-42, 2007.

[6] N. Nur Apriliyanti, "Uji Potensi Racun Ekstrak Daun Bintaro (Cerbera odollam Gaertn) Sebagai Bioinsektisida Terhadap Mortalitas Larva Plutella Xylostella Pada Tanaman Kubis (Brassica oleracea)," 2016.

[7] S. Utami, "Aktivitas insektisida bintaro (Cerbera odollam Gaertn) terhadap hama Eurema spp. pada skala laboratorium," Jurnal Penelitian Hutan Tanaman, vol. 7, no. 4, pp. 211-220, 2010.

[8] Z. AMILASARIY, H. Herlina, and N. A. Fithri, "Uji toksisitas akut ekstrak biji palem putri (Adonidia merrillii (Becc.) Becc) terhadap tikus putih betina galur wistar dengan fixed dose procedure," 2015.

[9] R. Riyanto, "Kepadatan, Pola Distribusi dan Peranan Semut pada Tanaman di Sekitar Lingkungan Tempat Tinggal," Jurnal Penelitian Sains (JPS), vol. 10, no. 2, pp. 241-253, 2007.

[10] M. Iftikhar, M. A. Khan, and S. Haider, "Comparative Efficacy of Insecticides and Plant Extracts for Management of ChiLCV Disease in Relation to Epidemiology," 2017.

[11] M. S. D. Permadi and H. Fitrihidajati, "Pengaruh Pemberian Ekstrak Batang Brotowali (Tinospora crispa) terhadap Mortalitas Kutu Daun (Aphis gossypii)," LenteraBio, vol. 8, no. 2, 2019.

[12] R. Pavela, "History, presence and perspective of using plant extracts as commercial botanical insecticides and farm products for protection against insects-a review," Plant Protection Science, vol. 52, no. 4, pp. 229-241, 2016.

[13] F. Arfianto, "Pengendalian hama kutu daun coklat pada tanaman cabe mengggunakan pestisida organik ekstrak serai wangi," Anterior Jurnal, vol. 16, no. 1, pp. 57-66, 2016.

[14] M. S. Saleem, T. S. Batool, M. F. Akbar, S. Raza, and S. Shahzad, "Efficiency of botanical pesticides against some pests infesting hydroponic cucumber, cultivated under greenhouse conditions," Egyptian Journal of Biological Pest Control, vol. 29, no. 1, p. 37, 2019.
[15] A. Cruz-Estrada, M. Gamboa-Angulo, R. BorgesArgáez, and E. Ruiz-Sánchez, "Insecticidal effects of plant extracts on immature whitefly Bemisia tabaci Genn.(Hemiptera: Aleyroideae)," Electronic Journal of Biotechnology, vol. 16, no. 1, pp. 6-6, 2013.

[16] A. Khan et al., "Efficacy of a biopesticide and synthetic pesticides against tobacco aphid, Myzus persicae Sulz.(Homoptera, Aphididae), on tobacco in Peshawar," Journal of Entomology and Zoology Studies, vol. 4, pp. 371-373, 2015.

[17] K. Elango, S. Sridharan, P. Saravanan, and S. Balakrishnan, "Laboratory evaluation of insecticides and biopesticides against pomegranate aphid Aphis punicae Passerini," IJCS, vol. 5, no. 5, pp. 1810-1812, 2017.

[18] N. Agustina, M. I. Pramudi, and N. Aidawati, "Pengaruh Larutan Daun Gamal (Gliricidia sepium) Terhadap Mortalitas Kutu Daun Aphis gossypii) pada Cabai (Capsicum annum L," Jurnal Proteksi Tanaman TROPIKA, vol. 2, no. 1, pp. 86-91, 2019.

[19] L. Quesada-Romero, C. Fernández-Galleguillos, J. Bergmann, M. A. Bravo, and E. Fuentes-Contreras, "Antifeedant and insecticidal activity of Polygonum persicaria extracts on Nomophila indistinctalis," Journal of Pharmacy \& Pharmacognosy Research, vol. 5, no. 3, pp. 167-173, 2017.

[20] R. R. Kinansi, S. W. Handayani, D. Prastowo, and A. O. Y. Sudarno, "Efektivitas Ekstrak Etanol Akar Tuba (Derris elliptica) terhadap Kematian Periplaneta americana dengan Metode Spraying," Balaba: Jurnal Litbang Pengendalian Penyakit Bersumber Binatang Banjarnegara, pp. 147-158, 2018.

\section{Creative Commons Attribution License 4.0 (Attribution 4.0 International, CC BY 4.0)}

This article is published under the terms of the Creative Commons Attribution License 4.0 https://creativecommons.org/licenses/by/4.0/deed.en_US 
Table 1a. The average population of Bemisia tabaci insects in chili plants with various concentrations treatment of bintaro leaf extract in 1-10 days after pest infestation

\begin{tabular}{|c|c|c|c|c|c|c|c|c|}
\hline \multirow{2}{*}{ Treatment } & \multicolumn{8}{|c|}{ observation on the length time (days) after inoculum source infestation } \\
\hline & 1 & & 3 & 5 & 6 & & 8 & 10 \\
\hline $\mathrm{K}_{0} \mathrm{~F}_{1}$ & 35.6 & $\mathrm{bc}$ & $5.4 \mathrm{ab}$ & $3.6 \mathrm{~cd}$ & 4.6 & a & $5.4 \mathrm{ab}$ & $7.2 \mathrm{bc}$ \\
\hline $\mathrm{K}_{1} \mathrm{~F}_{1}$ & 109.6 & a & 17.8 a & 34.4 & 27.6 & a & $30.4 \quad \mathrm{a}$ & 42.8 \\
\hline $\mathrm{K}_{2} \mathrm{~F}_{1}$ & 43.7 & $\mathrm{bc}$ & $7.0 \mathrm{ab}$ & 0.0 & 13.2 & a & $13.4 \mathrm{ab}$ & $21.0 \mathrm{ab}$ \\
\hline $\mathrm{K}_{3} \mathrm{~F}_{1}$ & 28.4 & $\mathrm{c}$ & $2.6 \mathrm{~b}$ & $1.6 \mathrm{~d}$ & 3.0 & $\mathrm{a}$ & $1.6 \mathrm{~b}$ & $1.8 \mathrm{c}$ \\
\hline $\mathrm{K}_{4} \mathrm{~F}_{1}$ & 33.6 & $\mathrm{bc}$ & $4.4 \mathrm{ab}$ & 0.0 & 16.4 & $\mathrm{a}$ & $22.0 \mathrm{ab}$ & $25.2 \mathrm{abc}$ \\
\hline $\mathrm{K}_{5} \mathrm{~F}_{1}$ & 44.0 & $\mathrm{bc}$ & $1.6 \mathrm{~b}$ & 0.6 & 5.0 & $\mathrm{a}$ & $5.4 \mathrm{ab}$ & 9.4 bc \\
\hline $\mathrm{K}_{0} \mathrm{~F}_{2}$ & 38.6 & $\mathrm{bc}$ & $8 \mathrm{ab}$ & $15.0 \mathrm{abc}$ & 14.0 & $\mathrm{a}$ & $17.6 \mathrm{ab}$ & $24.0 \mathrm{ab}$ \\
\hline $\mathrm{K}_{1} \mathrm{~F}_{2}$ & 62.0 & $\mathrm{bc}$ & $3.4 \mathrm{ab}$ & $5.4 \mathrm{bcd}$ & 8.0 & $\mathrm{a}$ & $11.6 \mathrm{ab}$ & 11.8 bc \\
\hline $\mathrm{K}_{2} \mathrm{~F}_{2}$ & 28.8 & $\mathrm{bc}$ & $4.4 \mathrm{ab}$ & $4.2 \mathrm{~cd}$ & 6.2 & $\mathrm{a}$ & $7.2 \mathrm{ab}$ & $19.6 a b c$ \\
\hline $\mathrm{K}_{3} \mathrm{~F}_{2}$ & 30.2 & c & $11.6 \mathrm{ab}$ & $19.4 \mathrm{ab}$ & 21.8 & $\mathrm{a}$ & $28.4 \mathrm{ab}$ & $27.2 \mathrm{ab}$ \\
\hline $\mathrm{K}_{4} \mathrm{~F}_{2}$ & 35.0 & $\mathrm{bc}$ & $6.6 \mathrm{ab}$ & $5.6 \mathrm{bcd}$ & 9.6 & $\mathrm{a}$ & $16.4 \mathrm{ab}$ & $14.2 \mathrm{abc}$ \\
\hline $\mathrm{K}_{5} \mathrm{~F}_{2}$ & 76.8 & $a b$ & $3.6 \mathrm{ab}$ & $6.4 \mathrm{bcd}$ & 9.2 & $\mathrm{a}$ & $11.4 \mathrm{ab}$ & $20.2 \mathrm{abc}$ \\
\hline
\end{tabular}

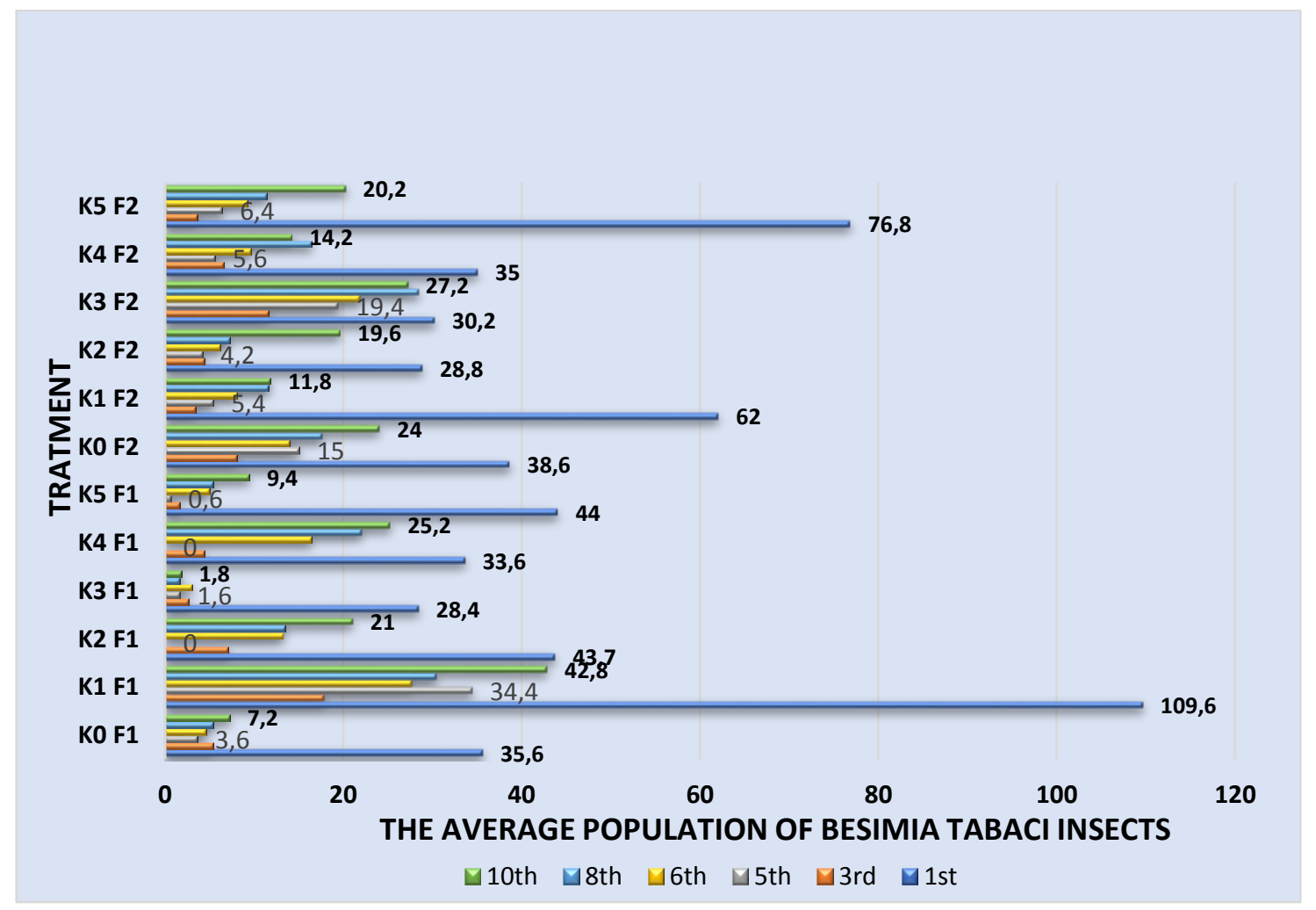

Figure 1.a.The average population of Bemisia tabasi insect in chili plants with various concentration of bintaro leaf extract in 1-10 days after infestation 
Table $1 \mathrm{~b}$. The average population of Bemisia tabaci insects in chili plants with various concentrations treatment of bintaro leaf extract in 12-20 days after pest infestation

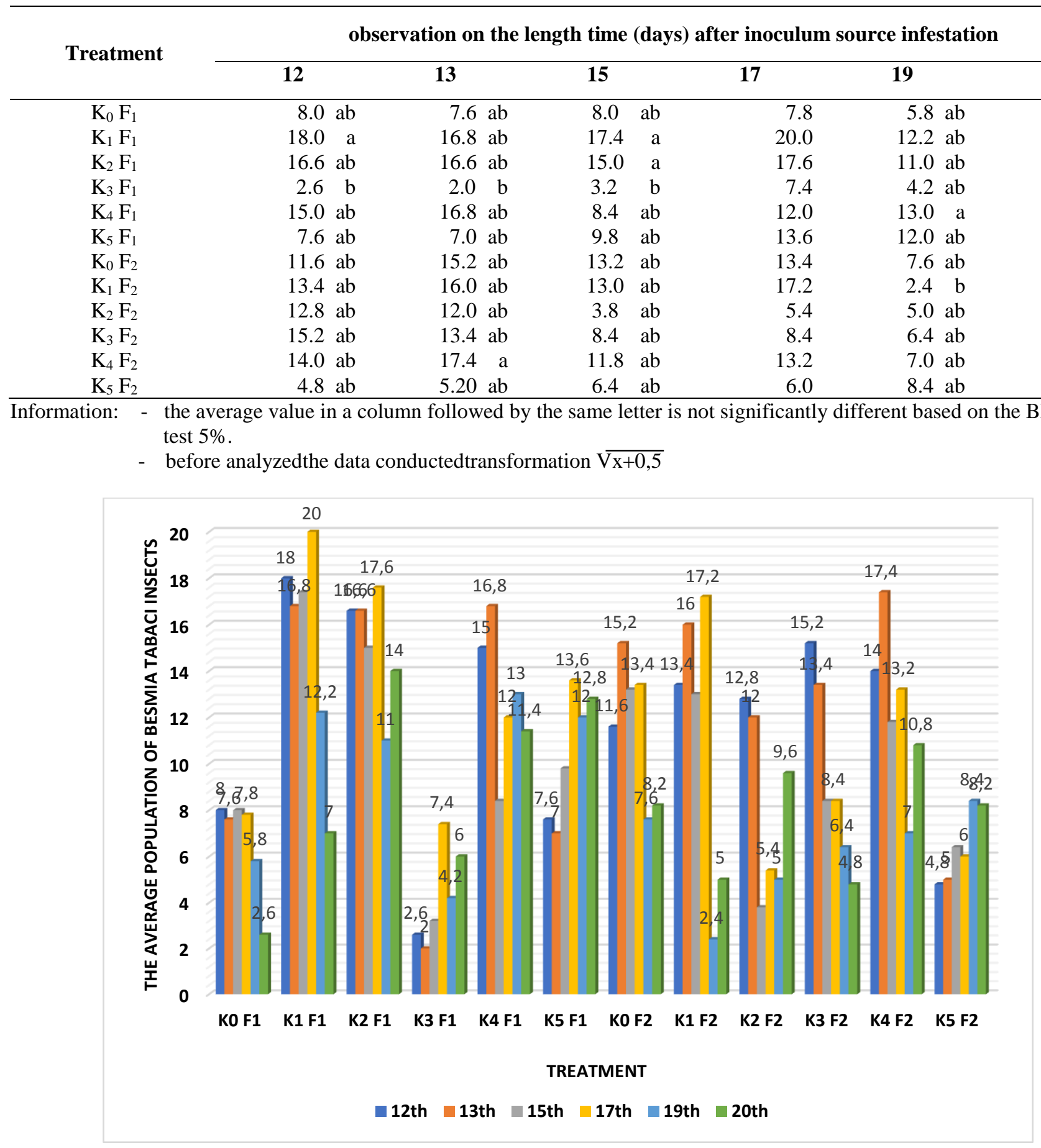

Figure 1.b.. The average population of Bemisia tabasi insect in chili plants with various concentration of bintaro leaf extract in 12-20 days after infestation 
Table 2.a The average population of Aphis gossypii insects in chili plants with various concentrations treatment of bintaro leaf extract in 1-10 days after pest infestation

\begin{tabular}{|c|c|c|c|c|c|c|c|c|}
\hline \multirow{2}{*}{ Treatment } & \multicolumn{8}{|c|}{ observation on the length time (days) after inoculum source infestation } \\
\hline & 1 & & 3 & 5 & 6 & 8 & & 10 \\
\hline $\mathrm{K}_{0} \mathrm{~F}_{1}$ & 35.6 & $\mathrm{bc}$ & $38.8 \mathrm{ab}$ & $46.2 \mathrm{ab}$ & $53.2 \quad \mathrm{a}$ & $28.0 \mathrm{ab}$ & 29.0 & abc \\
\hline $\mathrm{K}_{1} \mathrm{~F}_{1}$ & 109.6 & a & $53.6 \mathrm{ab}$ & $64.8 \mathrm{ab}$ & $68.4 \quad \mathrm{a}$ & $30.2 \mathrm{~b}$ & 47.8 & $\mathrm{ab}$ \\
\hline $\mathrm{K}_{2} \mathrm{~F}_{1}$ & 43.7 & $\mathrm{c}$ & $59.0 \mathrm{ab}$ & $55.2 \mathrm{ab}$ & $42.2 \mathrm{ab}$ & $33.0 \mathrm{ab}$ & 39.4 & $a b c$ \\
\hline $\mathrm{K}_{3} \mathrm{~F}_{1}$ & 28.4 & $\mathrm{c}$ & $24.8 \mathrm{ab}$ & $26.0 \mathrm{ab}$ & $57.8 \quad \mathrm{a}$ & $22.2 \mathrm{ab}$ & 50.8 & $a b c$ \\
\hline $\mathrm{K}_{4} \mathrm{~F}_{1}$ & 33.6 & $\mathrm{bc}$ & $32.2 \mathrm{ab}$ & $46.4 \mathrm{ab}$ & $49.2 \mathrm{ab}$ & $21.4 \quad b$ & 29.0 & $a b c$ \\
\hline $\mathrm{K}_{5} \mathrm{~F}_{1}$ & 44.0 & $\mathrm{bc}$ & $38.0 \mathrm{ab}$ & $33.8 \mathrm{ab}$ & $35.2 \mathrm{ab}$ & $24.6 \mathrm{ab}$ & 24.2 & bc \\
\hline $\mathrm{K}_{0} \mathrm{~F}_{2}$ & 38.6 & $\mathrm{bc}$ & $50.4 \mathrm{ab}$ & $41.0 \mathrm{ab}$ & $61.0 \quad \mathrm{a}$ & $29.0 \mathrm{ab}$ & 37.4 & $a b c$ \\
\hline $\mathrm{K}_{1} \mathrm{~F}_{2}$ & 62.0 & $\mathrm{bc}$ & $46.8 \mathrm{ab}$ & $48.6 \mathrm{ab}$ & $38.8 \mathrm{ab}$ & $23.4 \mathrm{ab}$ & 35.0 & $a b c$ \\
\hline $\mathrm{K}_{2} \mathrm{~F}_{2}$ & 28.8 & $\mathrm{bc}$ & $36.4 \mathrm{ab}$ & $45.8 \mathrm{ab}$ & $66.2 \mathrm{a}$ & $37.8 \mathrm{ab}$ & 42.4 & $a b c$ \\
\hline $\mathrm{K}_{3} \mathrm{~F}_{2}$ & 30.2 & $\mathrm{c}$ & $18.2 \mathrm{ab}$ & $24.8 \mathrm{ab}$ & $30.8 \mathrm{ab}$ & $21.8 \mathrm{ab}$ & 31.8 & $a b c$ \\
\hline $\mathrm{K}_{4} \mathrm{~F}_{2}$ & 35.0 & $\mathrm{bc}$ & $22.8 \quad b$ & $15.8 \quad b$ & $9.2 \mathrm{~b}$ & $11.4 \quad b$ & 16.6 & $\mathrm{c}$ \\
\hline $\mathrm{K}_{5} \mathrm{~F}_{2}$ & 76.8 & $a b$ & $59.8 \mathrm{a}$ & $72.2 \quad \mathrm{a}$ & $70.2 \mathrm{a}$ & 56.4 a & 57.6 & $\mathrm{a}$ \\
\hline
\end{tabular}

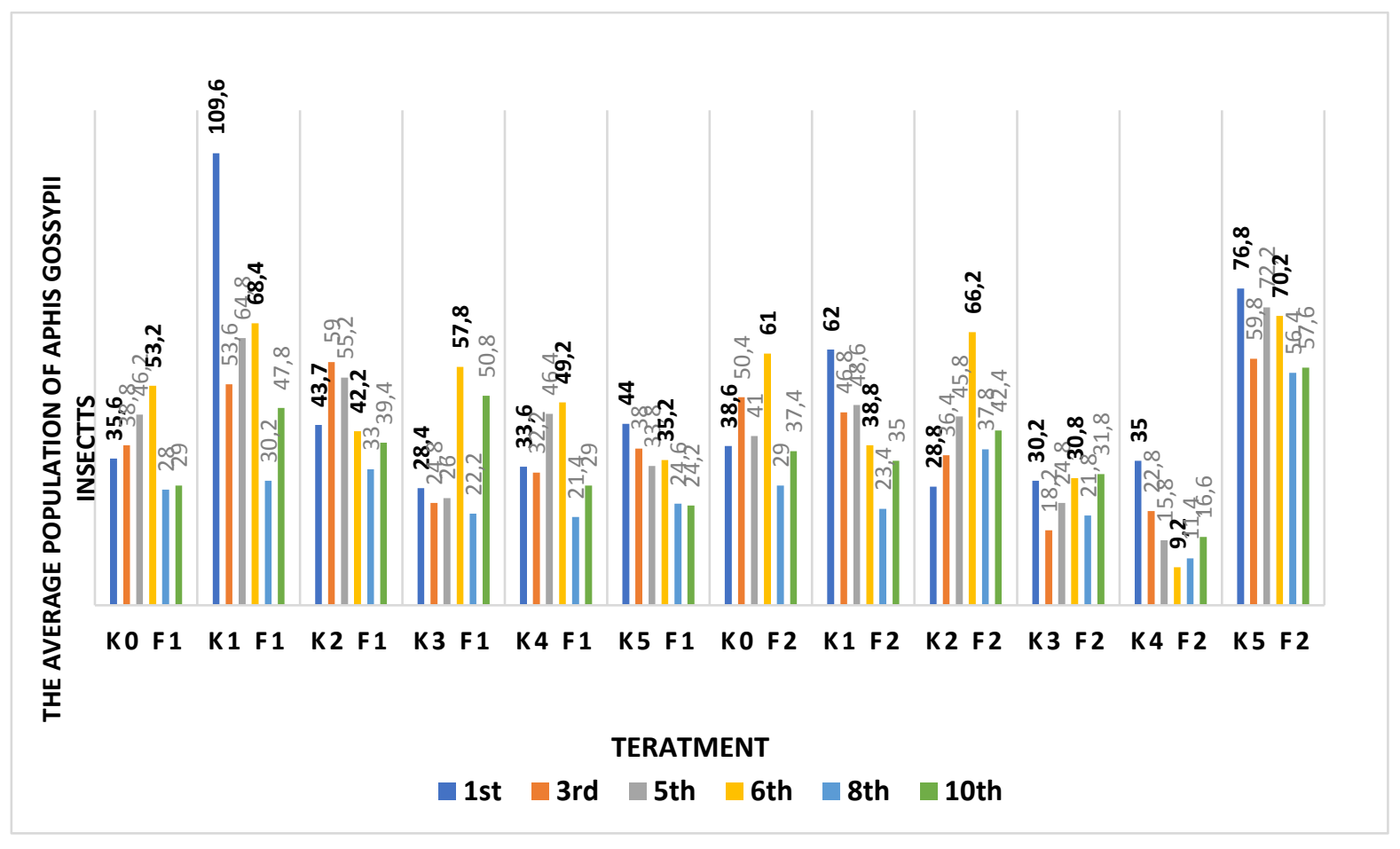

Figure 2.a.The average population of Aphis gossypii insects in chili plants with various concentrations treatment of bintaro leaf extract in 1-10 days after pest infestation 
Table 2.b. The average population of Aphis gossypii insects in chili plants with various concentrations treatment of bintaro leaf extract in 12-20 days after pest infestation

\begin{tabular}{|c|c|c|c|c|c|c|}
\hline \multirow{2}{*}{ Treatment } & \multicolumn{6}{|c|}{ observation on the length time (days) after inoculum source infestation } \\
\hline & 12 & 13 & 15 & 17 & 19 & 20 \\
\hline $\mathrm{K}_{0} \mathrm{~F}_{1}$ & $23.0 \mathrm{ab}$ & $18.6 \mathrm{abc}$ & 18.2 & $23.4 \mathrm{~cd}$ & $14.2 \mathrm{~b}$ & $24.2 \mathrm{ab}$ \\
\hline $\mathrm{K}_{1} \mathrm{~F}_{1}$ & $36.8 \mathrm{a}$ & 37.8 & $47.8 \quad \mathrm{ab}$ & $53.6 \mathrm{ab}$ & $23.4 \mathrm{ab}$ & $29.2 \mathrm{ab}$ \\
\hline $\mathrm{K}_{2} \mathrm{~F}_{1}$ & $22.6 \mathrm{ab}$ & $24.0 \mathrm{abc}$ & $31.0 \mathrm{abc}$ & 28.0abcd & $19.8 \mathrm{ab}$ & $20.6 \mathrm{ab}$ \\
\hline $\mathrm{K}_{3} \mathrm{~F}_{1}$ & $22.6 \mathrm{ab}$ & $31.8 \mathrm{ab}$ & $42.2 \mathrm{ab}$ & 36.8abcd & $23.4 \mathrm{ab}$ & $20.0 \mathrm{ab}$ \\
\hline $\mathrm{K}_{4} \mathrm{~F}_{1}$ & $20.4 \mathrm{ab}$ & $19.8 \mathrm{abc}$ & 21.0 & $17.4 \mathrm{~d}$ & $15.8 \mathrm{~b}$ & $23.8 \mathrm{ab}$ \\
\hline $\mathrm{K}_{5} \mathrm{~F}_{1}$ & $18.8 \quad b$ & $16.0 \mathrm{bc}$ & $31.2 \mathrm{abc}$ & 31.0abcd & $21.4 \mathrm{ab}$ & $28.4 \mathrm{ab}$ \\
\hline $\mathrm{K}_{0} \mathrm{~F}_{2}$ & $26.0 \mathrm{ab}$ & $22.6 \mathrm{abc}$ & $48.2 \quad \mathrm{a}$ & $44.2 \mathrm{abc}$ & $25.6 \mathrm{ab}$ & $30.8 \mathrm{ab}$ \\
\hline $\mathrm{K}_{1} \mathrm{~F}_{2}$ & $30.0 \mathrm{ab}$ & $30.6 \mathrm{ab}$ & 49.6 & 59.8 & $33.8 \quad \mathrm{a}$ & $34.4 \mathrm{a}$ \\
\hline $\mathrm{K}_{2} \mathrm{~F}_{2}$ & $34.8 \mathrm{ab}$ & $33.4 \mathrm{ab}$ & $46.4 \mathrm{ab}$ & $53.0 \mathrm{ab}$ & $34.2 \mathrm{a}$ & $32.8 \mathrm{ab}$ \\
\hline $\mathrm{K}_{3} \mathrm{~F}_{2}$ & $19.6 \mathrm{~b}$ & $17.6 \mathrm{abc}$ & $42.8 \mathrm{ab}$ & 40.8abcd & $21.0 \mathrm{ab}$ & $25.2 \mathrm{ab}$ \\
\hline $\mathrm{K}_{4} \mathrm{~F}_{2}$ & $13.0 \mathrm{ab}$ & $10.4 \mathrm{c}$ & $24.4 \mathrm{bc}$ & $24.8 \mathrm{bcd}$ & $14.4 \mathrm{~b}$ & $18.8 \mathrm{~b}$ \\
\hline $\mathrm{K}_{5} \mathrm{~F}_{2}$ & $29.8 \mathrm{ab}$ & $31.0 \mathrm{ab}$ & 46.2 & $45.8 \mathrm{ab}$ & $26.4 \mathrm{ab}$ & $24.8 \mathrm{ab}$ \\
\hline
\end{tabular}

Information: - the average value in a column followed by the same letter is not significantly different based on the BNT/LSD test $5 \%$.

- before analyzedthe data conductedtransformation $\overline{\mathrm{V}+0,5}$

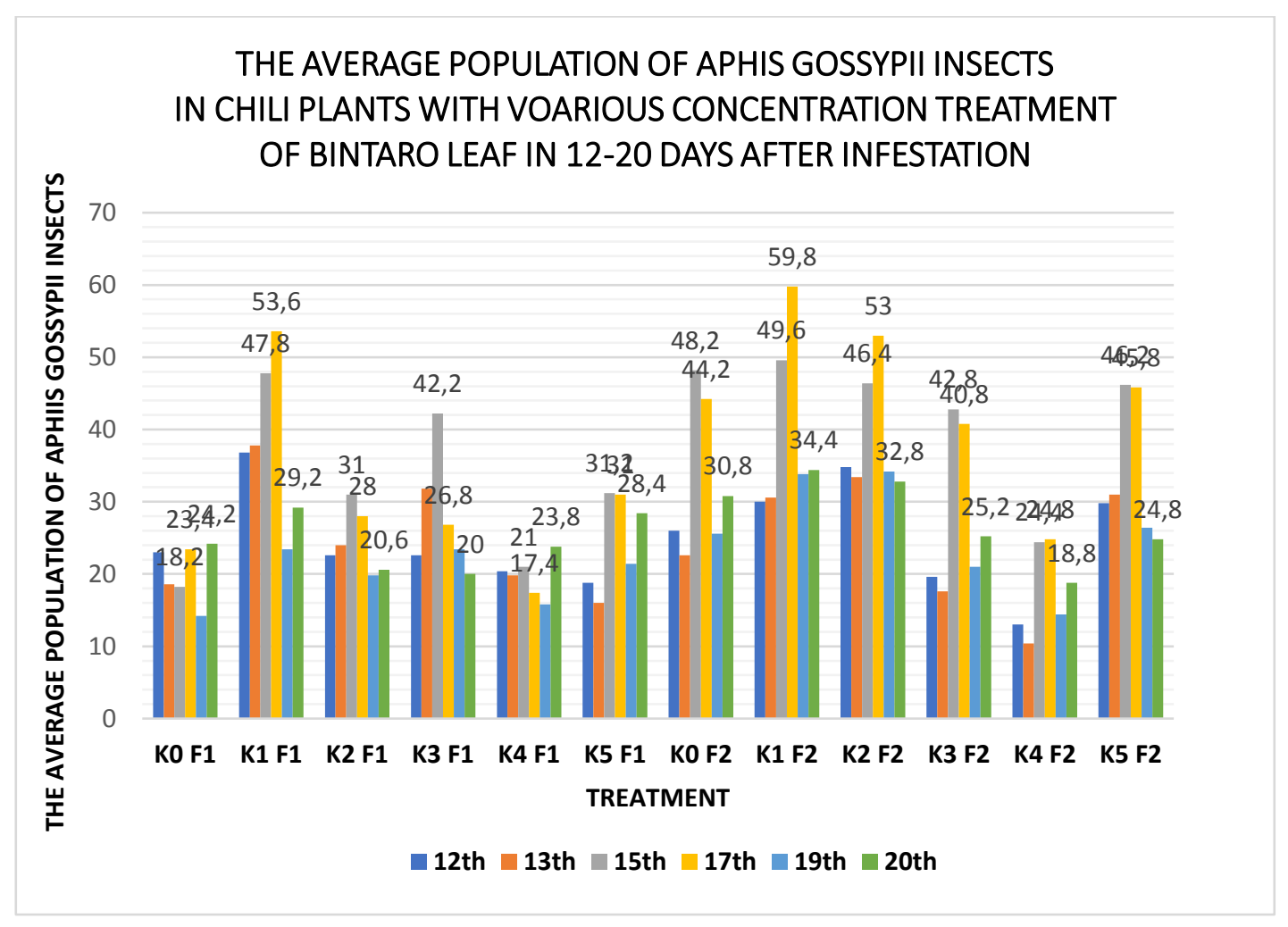

Figure 2.b. The average population of Aphis gossypii insects in chili plants with various concentrations treatment of bintaro leaf extract in 12-20 days after pest infestation 
Table 3.a.The average population of black ant in chili plants with various concentrations treatment of bintaro leaf extract in 110 days after pest infestation

\begin{tabular}{|c|c|c|c|c|c|c|c|c|c|}
\hline \multirow{2}{*}{ Treatment } & \multicolumn{9}{|c|}{ observation on the length time (days) after inoculum source infestation } \\
\hline & $\mathbf{1}$ & 3 & & 5 & & 6 & 8 & 10 & \\
\hline $\mathrm{K}_{0} \mathrm{~F}_{1}$ & $8.2 \mathrm{ab}$ & 4.4 & a & 8.6 & a & $8.2 \mathrm{ab}$ & $8.8 \mathrm{ab}$ & 4.8 & \\
\hline $\mathrm{K}_{1} \mathrm{~F}_{1}$ & $18.2 \mathrm{a}$ & 8.6 & a & 11.4 & a & $16.2 \mathrm{ab}$ & $12.6 \mathrm{ab}$ & 6.4 & $\mathrm{a}$ \\
\hline $\mathrm{K}_{2} \mathrm{~F}_{1}$ & $8.0 \mathrm{ab}$ & 11.4 & $\mathrm{a}$ & 9.4 & $\mathrm{a}$ & $8.2 \mathrm{ab}$ & $11.2 \mathrm{ab}$ & 6.0 & $\mathrm{a}$ \\
\hline $\mathrm{K}_{3} \mathrm{~F}_{1}$ & $1.6 \mathrm{~b}$ & 0.8 & $\mathrm{a}$ & 2.4 & $\mathrm{a}$ & $7.6 \mathrm{ab}$ & $7.6 \mathrm{ab}$ & 13.6 & $\mathrm{a}$ \\
\hline $\mathrm{K}_{4} \mathrm{~F}_{1}$ & $10.4 \mathrm{ab}$ & 12.0 & a & 11.2 & a & $15.2 \mathrm{ab}$ & $8.0 \mathrm{ab}$ & 4.6 & $\mathrm{a}$ \\
\hline $\mathrm{K}_{5} \mathrm{~F}_{1}$ & $12.0 \mathrm{ab}$ & 4.4 & a & 7.6 & $\mathrm{a}$ & $6.8 \mathrm{ab}$ & $4.0 \mathrm{ab}$ & 7.6 & $\mathrm{a}$ \\
\hline $\mathrm{K}_{0} \mathrm{~F}_{2}$ & $9.6 \mathrm{ab}$ & 5.2 & $\mathrm{a}$ & 16.0 & $\mathrm{a}$ & $10.4 \mathrm{ab}$ & $6.6 \mathrm{ab}$ & 3.6 & $\mathrm{a}$ \\
\hline $\mathrm{K}_{1} \mathrm{~F}_{2}$ & $6.2 \mathrm{~b}$ & 0.0 & $\mathrm{a}$ & 1.4 & $\mathrm{a}$ & $5.8 \mathrm{ab}$ & $0.8 \quad b$ & 5.0 & $\mathrm{a}$ \\
\hline $\mathrm{K}_{2} \mathrm{~F}_{2}$ & $11.2 \mathrm{ab}$ & 8.2 & $\mathrm{a}$ & 13.4 & $\mathrm{a}$ & $16.0 \mathrm{ab}$ & $7.4 \mathrm{ab}$ & 7.6 & $\mathrm{a}$ \\
\hline $\mathrm{K}_{3} \mathrm{~F}_{2}$ & $5.2 \mathrm{ab}$ & 4.4 & a & 3.4 & $\mathrm{a}$ & $3.6 \mathrm{ab}$ & $5.8 \mathrm{ab}$ & 5.2 & $\mathrm{a}$ \\
\hline $\mathrm{K}_{4} \mathrm{~F}_{2}$ & $1.6 \mathrm{~b}$ & 1.6 & $\mathrm{a}$ & 1.0 & $\mathrm{a}$ & $1.2 \mathrm{~b}$ & $1.8 \mathrm{~b}$ & 0.0 & $\mathrm{a}$ \\
\hline $\mathrm{K}_{5} \mathrm{~F}_{2}$ & $11.0 \mathrm{ab}$ & 9.6 & $\mathrm{a}$ & 9.6 & $\mathrm{a}$ & $16.8 \mathrm{a}$ & $15.6 \mathrm{a}$ & 8.6 & $\mathrm{a}$ \\
\hline
\end{tabular}

Table 3.b.The average population of black ant in chili plants with various concentrations treatment of bintaro leaf extract in 1220 days after pest infestation

\begin{tabular}{|c|c|c|c|c|c|c|}
\hline \multirow{2}{*}{ Treatment } & \multicolumn{6}{|c|}{ observation on the length time (days) after inoculum source infestation } \\
\hline & 12 & 13 & 15 & 17 & 19 & 20 \\
\hline $\mathrm{K}_{0} \mathrm{~F}_{1}$ & $3.0 \mathrm{ab}$ & $3.2 \mathrm{ab}$ & $2.2 \quad b c$ & $1.6 \mathrm{ab}$ & 0.0 & $1.8 \mathrm{ab}$ \\
\hline $\mathrm{K}_{1} \mathrm{~F}_{1}$ & $7.8 \mathrm{a}$ & $8.6 \mathrm{ab}$ & $11.0 \quad \mathrm{a}$ & $7.4 \mathrm{ab}$ & $6.8 \mathrm{abc}$ & $3.2 \mathrm{ab}$ \\
\hline $\mathrm{K}_{2} \mathrm{~F}_{1}$ & $4.2 \mathrm{ab}$ & $4.8 \mathrm{ab}$ & $5.0 \mathrm{abc}$ & $5.2 \mathrm{ab}$ & $8.8 \quad \mathrm{a}$ & $2.6 \mathrm{ab}$ \\
\hline $\mathrm{K}_{3} \mathrm{~F}_{1}$ & $5.2 \mathrm{ab}$ & $11.2 \mathrm{a}$ & $2.6 \mathrm{bc}$ & $3.6 \mathrm{ab}$ & $3.2 \mathrm{abc}$ & $2.0 \mathrm{ab}$ \\
\hline $\mathrm{K}_{4} \mathrm{~F}_{1}$ & $5.0 \mathrm{ab}$ & $4.8 \mathrm{ab}$ & $0.6 \mathrm{c}$ & $0.8 \mathrm{~b}$ & $0.4 \mathrm{bc}$ & $0.0 \mathrm{~b}$ \\
\hline $\mathrm{K}_{5} \mathrm{~F}_{1}$ & $4.4 \mathrm{ab}$ & $4.0 \mathrm{ab}$ & $3.0 \mathrm{abc}$ & $2.4 \mathrm{ab}$ & $3.4 \mathrm{abc}$ & $3.4 \mathrm{ab}$ \\
\hline $\mathrm{K}_{0} \mathrm{~F}_{2}$ & $1.6 \mathrm{ab}$ & $2.0 \mathrm{ab}$ & $6.2 \mathrm{ab}$ & $3.8 \mathrm{ab}$ & $2.8 \mathrm{abc}$ & $1.6 \mathrm{ab}$ \\
\hline $\mathrm{K}_{1} \mathrm{~F}_{2}$ & $2.4 \mathrm{ab}$ & $1.2 \mathrm{~b}$ & $6.0 \mathrm{ab}$ & $4.8 \mathrm{ab}$ & $3.4 \mathrm{abc}$ & $3.4 \mathrm{ab}$ \\
\hline $\mathrm{K}_{2} \mathrm{~F}_{2}$ & $5.4 \mathrm{ab}$ & $6.8 \mathrm{ab}$ & $4.6 \mathrm{abc}$ & $3.8 \mathrm{ab}$ & $5.6 \mathrm{abc}$ & $3.2 \mathrm{ab}$ \\
\hline $\mathrm{K}_{3} \mathrm{~F}_{2}$ & $0.4 \quad b$ & $1.6 \mathrm{~b}$ & $2.4 a b c$ & $4.2 \mathrm{ab}$ & $3.8 \mathrm{abc}$ & $4.0 \mathrm{a}$ \\
\hline $\mathrm{K}_{4} \mathrm{~F}_{2}$ & $1.6 \mathrm{ab}$ & $2.4 \mathrm{ab}$ & $0.6 \quad \mathrm{c}$ & $1.6 \mathrm{ab}$ & $1.4 \mathrm{abc}$ & $1.8 \mathrm{ab}$ \\
\hline $\mathrm{K}_{5} \mathrm{~F}_{2}$ & $6.2 \quad \mathrm{a}$ & $8.6 \mathrm{ab}$ & $6.6 a b c$ & $8.6 \quad \mathrm{a}$ & $4.2 \mathrm{ab}$ & $2.8 \mathrm{ab}$ \\
\hline
\end{tabular}


Table 4. The average level of damage to chili due to aphids (Aphids gossypii and Bemesia tabaci) with the treatment of various concentrations of bintaro leaf extract

\begin{tabular}{lcl}
\hline \multicolumn{1}{c}{ Treatment } & $\begin{array}{c}\text { Average damage } \\
\text { score }\end{array}$ & information \\
\hline $\mathrm{K}_{0} \mathrm{~F}_{1}$ (concentration of 0\% frequency once a week) & $3.2 \mathrm{a}$ & heavily damaged \\
$\mathrm{K}_{1} \mathrm{~F}_{1}$ (concentration of $2.5 \%$ frequency once a week) & $2.4 \mathrm{ab}$ & moderately damaged \\
$\mathrm{K}_{2} \mathrm{~F}_{1}$ (concentration of5.0\% frequency once a week) & $3.0 \mathrm{ab}$ & heavily damaged \\
$\mathrm{K}_{3} \mathrm{~F}_{1}$ (concentration of7.5\% frequency once a week) & $2.6 \mathrm{ab}$ & moderately damaged \\
$\mathrm{K}_{4} \mathrm{~F}_{1}$ (concentration of $10 \%$ frequency once a week) & $3.4 \mathrm{a}$ & heavily damaged \\
$\mathrm{K}_{5} \mathrm{~F}_{1}$ (concentration of12.5\% frequency once a week) & $2.8 \mathrm{ab}$ & moderately damaged \\
$\mathrm{K}_{0} \mathrm{~F}_{2}$ (concentration of 0\% frequency twice a week) & $2.4 \mathrm{ab}$ & moderately damaged \\
$\mathrm{K}_{1} \mathrm{~F}_{2}$ (concentration of $2.5 \%$ frequency twice a week) & $2.8 \mathrm{ab}$ & moderately damaged \\
$\mathrm{K}_{2} \mathrm{~F}_{2}$ (concentration of5.0\% frequency twice a week) & $2.2 \mathrm{ab}$ & moderately damaged \\
$\mathrm{K}_{3} \mathrm{~F}_{2}$ (concentration of $7.5 \%$ frequency twice a week) & $1.6 \mathrm{~b}$ & lightly damaged \\
$\mathrm{K}_{4} \mathrm{~F}_{2}$ (concentration of $10 \%$ frequency twice a week) & $2.4 \mathrm{ab}$ & moderately damaged \\
$\mathrm{K}_{5} \mathrm{~F}_{2}$ (concentration of $12.5 \%$ frequency twice a week) & $2.8 \mathrm{ab}$ & moderately damaged \\
\hline
\end{tabular}

Information: - the average value in a column followed by the same letter is not significantly different based on the BNT/LSD test $5 \%$.

- before analyzed the data conducted transformation $\overline{\mathrm{Vx}+0,5}$

Score 0: no damaged plants: healthy

Score 1: damaged plants $1 \mathrm{~s} / \mathrm{d} 20 \%$ : Very light damage

Score 2: damaged plants $21 \mathrm{~s} / \mathrm{d} 40 \% \quad$ : light damage

Score 3: damaged plants 41s/d 60\% : Medium damage

Score 4: damaged plants $61 \mathrm{~s} / \mathrm{d} 80 \% \quad$ : Heavy damage

Score 5: damaged plants $81 \mathrm{~s} / \mathrm{d} 100 \%$ : Very heavy damage

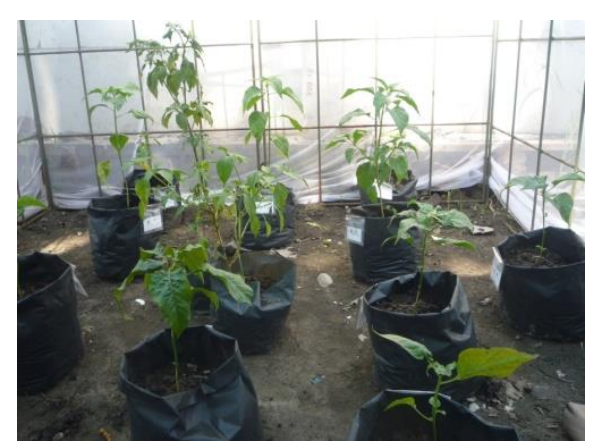

Figure 1. Experimental material for chilli plants in a mosquito net lid

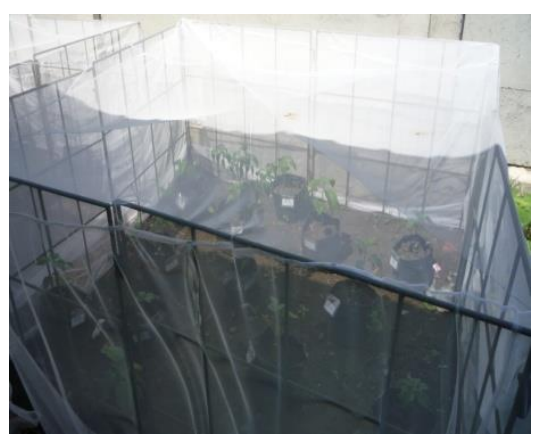

Figure 2. Mosquito net contain one test run 


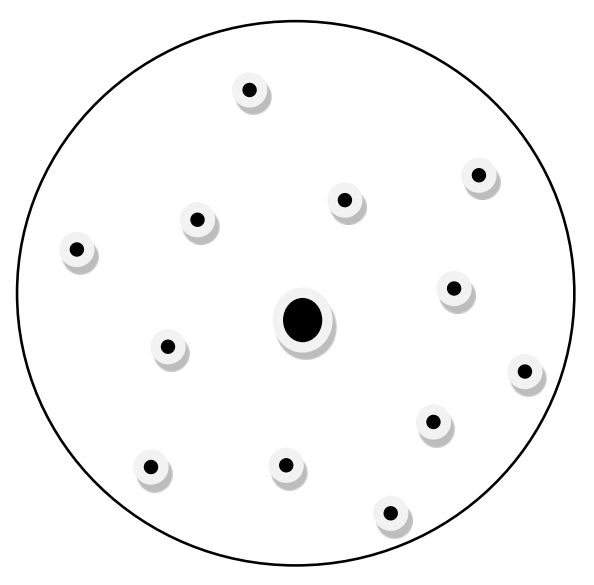

Information:

: inoculum source (release of test insects)

- : : host / feed that has been given treatment

Figure 3. Design of the placement of inoculum sources toward the treated plants

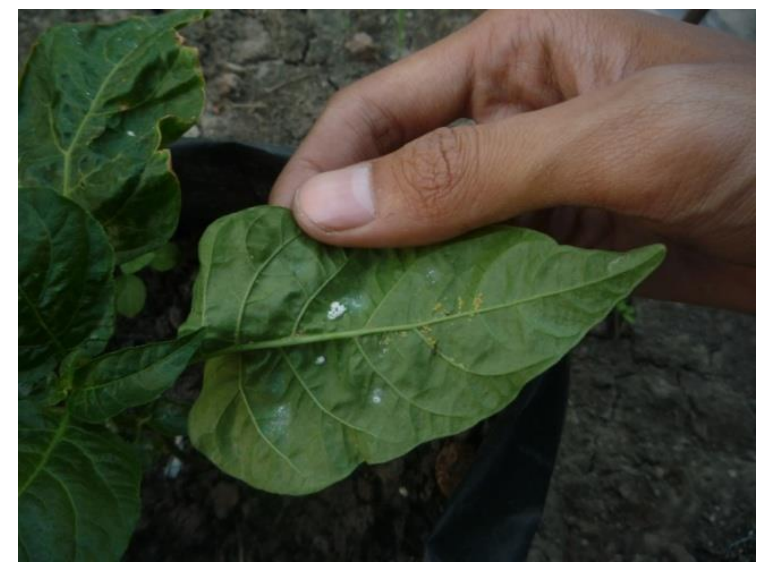

Figure 4.chili leaves with the pest of Bemisia tabaci (whitefly), Aphis gossypii (aphid) and Dolichoderus thoracicus (black ant) 